\title{
ACADEMIC STRESS AND COPING STRATEGY IN RELATION TO ACADEMIC ACHIEVEMENT
}

\author{
Abd. Basith ${ }^{1,2 *}$, Andi Syahputra ${ }^{2,3}$, Slamat Fitriyadi ${ }^{1}$, Rosmaiyadi ${ }^{1}$, Fitri $^{1}$, Susan Neni Triani ${ }^{1}$ \\ ${ }^{1}$ STKIP Singkawang, Indonesia \\ ${ }^{2}$ Central China Normal University, China \\ ${ }^{3}$ STAIN Teungku Dirundeng Meulaboh, Indonesia \\ *e-mail: abd-basith@stkipsingkawang.ac.id
}

\begin{abstract}
Stress on students is more common and varied. Therefore, a good coping strategy is needed in order to control stress and increase academic achievement. The purposes of this study are: 1) to describe the level of academic stress and coping strategy; 2) to investigate the effect of the differences of gender, age, marital status, years of study and degrees on academic stress and coping; and 3) to analyze the relationship between academic stress, coping and academic achievement. This research used a quantitative method with a survey approach. The population was 340 Indonesian students in Wuhan, China. The samples of 184 students ( 73 male and 111 female) were taken with a simple random sampling technique. The instruments used in collecting data are the Scale for Assessment Academic Stress and the Stress Coping Style Inventory. The results showed that academic stress was at a moderate level dominated by cognitive stress indicators. Coping was at a moderate level dominated by active emotional coping. Different demographic factors have a significant effect on academic stress and coping. Intercorrelation shows the relationship between several indicators of academic stress and coping but no significant relationship with academic achievement.
\end{abstract}

Keyword: academic achievement, coping, stress.

\section{STRES AKADEMIK DAN STRATEGI KOPING DALAM HUBUNGANNYA DENGAN PRESTASI AKADEMIK}

\begin{abstract}
Abstrak: Stres pada mahasiswa lebih banyak dan bervariatif sehingga membutuhkan koping yang baik agar dapat mengontrol stres dan dapat meningkatkan prestasi akademik. Tujuan penelitian ini adalah: 1) mendeskripsikan tingkat stres akademik dan koping; 2) menganalisis pengaruh perbedaan jenis kelamin, usia, status perkawinan, masa studi, dan gelar terhadap stres akademik dan koping; dan 3) menganalisis hubungan antara stres akademik dan koping dengan prestasi akademik. Penelitian ini menggunakan metode kuantitatif dengan pendekatan survei. Populasi berjumlah 340 pelajar Indonesia di Wuhan. Kemudian diambil sampelnya dengan teknik simple random sampling sebanyak 184 siswa (73 laki-laki dan 111 perempuan). Instrumen yang digunakan dalam pengumpulan data adalah Scale for Assessment Academic Stress dan Stress Coping Style Inventory. Hasil penelitian menunjukkan bahwa stres akademik berada pada tingkat sedang yang didominasi oleh indikator stres kognitif. Koping berada pada level sedang yang didominasi oleh koping emosional aktif. Faktor demografis yang berbeda berpengaruh signifikan terhadap stres akademik dan koping. Interkorelasi menunjukkan adanya hubungan antara beberapa indikator stres akademik dan koping tetapi tidak memiliki hubungan yang signifikan dengan prestasi akademik.
\end{abstract}

Kata Kunci: prestasi akademik, koping, stres.

\section{INTRODUCTION}

Studying abroad certainly hasits challenges for a student because it has many differences from studying at home. Some of these differences can include differences in language, differences in the learning environment, differences in learning culture, as well as differences in curriculum, which can then put academic pressure on students to cause stress. Bernstein, Penner, \& Clarke-Stewart (2008) views stress as a person's adjustment in dealing with stressors through negative cognitive, emotional, behavioral, and 
physiological processes. Stress is a condition that is caused by the interaction between individuals and the environment, giving rise to the perception of distance between demands, and comes from situations that originate in the biological, psychological, and social systems of individuals (Sarafino \& Smith, 2012).

Based on an academic perspective, stress is a disorder caused by academic stressors in teaching and learning or things related to learning activities (Kariv \& Heiman, 2005). Academic stress is described as a response that arises because there are too many demands and tasks to be done by students (Olejnik \& Holschuh, 2007). The number of assignments, competition with other students, failure, lack of money, lack of relationships between fellow students and teachers, noisy environment, semester system, and lack of learning resources is allegedly the causes of academic stress, and this is because the ability of individuals possessed inversely proportional to the demands from the learning environment that must be met (Agolla \& Ongori, 2009). The weak ability of students to overcome various learning problems that cause academic stress can be caused by a lack of knowledge, experience, and environmental support capacity for psychological needs (Stallard, 2004). Individuals who cannot solve various problems in learning will result in mental stress, causing frustration associated with academic failure or even unconsciousness of the possibility of failure (Lal, 2014).

Individuals respond to various stressors that cause academic stress through several elements in the body. Olejnik \& Holschuh (2007) divides the response into several things, namely 1) thoughts (loss of self-confidence, always thinking about failure, difficulty concentrating, thinking negatively about the future, thinking continuously about something that should be done; 2) feelings (anxious, afraid, irritable, moody, easily sad); 3) behavior (using drugs and alcoholic beverages, withdrawing from the environment, more or less eating and sleeping, crying without reason); 4) physiological (excessive sweat on the palms, heart beat faster, lips become drier, tired quickly, prone to headaches, stomach, and nausea). Alvin (2007) divides the factors that cause stress into two parts, namely internal factors (i.e., mindset, personality, and beliefs) and external factors (i.e., overly dense learning, high pressure for achievement, social status drive, and people parents who compete in terms of children's achievements).

In the academic environment, stress has a strong relationship with academic life experienced by students from the age of children to adults, based on the level of education that is pursued by these students (Govaerst \& Gregoire, 2004). Previous research states that students in tertiary institutions have a higher level of vulnerability to academic stress (Hicks \& Heastie, 2008). This is because stressors are more numerous and varied, causing the risk of stress to be higher (Hung, 2011). Therefore, it is essential to analyze the level of academic stress that is being transmitted by students. Not only that, but the strategy used also need to be explained so that they can be understood in depth related to student actions in responding to academic stress experienced. This needs to be done because naturally individuals will try to do various ways to overcome everything that creates pressure, both by positive and negative actions (Cooper \& Payne, 1991; Lazarus; 1976). The way that is done to overcome everything that can cause pressure is called coping (Santrock, 2003). Coping is also an attempt by an individual to neutralize or reduce the stress that occurs in him (Sarafino, 2002).

A transactional model is related to stress, and coping theory is a theoretical framework that is the process of overcoming stressful situations by focusing on assessments to evaluate hazards, threats, and challenges (Lazarus \& Folkman, 1984). In psychosocial adaptations during stressful conditions experienced by individuals, coping is seen as a stabilizing factor that can support individuals in controlling stress experienced (Bamuhair, Al Farhan, Althubaiti, Agha, Rahman, \& Ibrahim, 2015). Stress levels experienced by students will be effectively reduced if using a coping strategy correctly (Yusoff, 2010). Some researchers also found that students would be able to modify situations, produce more adaptive results, and also experience fewer depressive symptoms if they use coping strategy well (Lerner, 1995). However, not all coping behaviors that are done effectively to reduce stress (such as 
smoking and drinking alcohol) so that it can cause physiological and psychological illness in individuals (Price, 1985).

Folkman \& Lazarus (1985) revealed that the use of coping methods was focused on two things, namely problems and emotions (the basis of developing revisions of the Ways of Coping Checklist/WCC) used to test students and produced eight inventories, namely direct coping, alienation, control self, seeking social support, accepting responsibility, preventionavoidance, problem-solving plans and coping with positive assessments. The strategy that focuses on problems is usually used by individuals when dealing with various events that cause stress and can then be controlled. In contrast, a strategy that focuses on emotions is used by individuals when dealing with multiple functions that cause stress and then cannot be controlled (Lazarus \& Folkman, 1984). This is in line with the explanation that reveals that coping is a condition to reduce individual burdens so that it does not cause stress that is formed through behavior and thoughts (negative or positive) (Haber \& Runyon, 1984).

The explanation of academic stress and coping strategy above shows that a person who experiences stress naturally will engage in various coping behaviors (positive or negative) as an action to reduce the stress experienced. In addition, several studies also found a link between academic stress and coping strategy with academic achievement, as research conducted by Herath (2019) on undergraduate students in Sri Lanka. The method used was a survey involving 256 students (143 male students and 113 female students), which aimed to understand the relationship between academic stress and academic achievement. The results showed that there was a negative relationship between these variables $(r=-.536, p<.05)$. It means that reducing academic stress will have an impact on increasing academic achievement.

Yazon, Ang-Manaig, \& Tesoro (2017) investigated undergraduate students in the Philippines using descriptive - correlational methods, involving a sample of 60 students taken at random. The results confirmed that each dimension on the coping strategy had a positive and significant relationship with academic achievement $(r=.5226-.705, p<.001)$. Inversely proportional to several other studies which show that academic stress has no significant relationship with academic achievement (Mulinda \& Megawati, 2018), as well as coping strategies which have no relationship with academic achievement (Rahmah, 2013; Oktarisa \& Yursa, 2015).

The various explanations above show that studies related to academic stress and coping strategy with academic achievement are essential to do for students because they have a crucial role in student academic success. Therefore, this study seeks to explore these issues by formulating them into three research objectives, namely: 1) to describe the level of academic stress and coping strategy, 2) to investigate the effect of the differences of gender, age, marital status, years of study, and degrees on academic stress and coping strategy, 3) to analyze the relationship between academic stress and coping strategy with academic achievement.

\section{METHOD}

This research used a quantitative approach with a survey method. This approach is useful for studying samples from populations by collecting data in quantitative or numerical form, attitudes, or opinions (Creswell, 2014).

\section{Population and Sample}

The population in this study were all Indonesian students who were studying in Wuhan, China. Characteristics of students entering the study population are; 1) already have an academic achievement index, 2) are still active in attending face-to-face lectures, and thesis guidance. The population that met the characteristics of the study amounted to 340 students, then taken a sample of 184 students (male; 73 students and women: 111 student) using simple random sampling techniques. Table 1 displays data (frequency and percentage) related to demographic information from respondents sampled in this study. 
Table 1. Frequency and Percentage of Respondents Information

\begin{tabular}{llcc}
\hline $\begin{array}{l}\text { Demographic } \\
\text { Information }\end{array}$ & \multicolumn{2}{l}{ Frequency } \\
\hline Gender & Male & 73 & 39.7 \\
& Female & 111 & 60.3 \\
Age & $<20$ & 22 & 12 \\
& $20-30$ & 141 & 76.6 \\
& $31-40$ & 19 & 10.3 \\
& $>40$ & 2 & 1.1 \\
Marital & Single & 149 & 81 \\
status & Married & 35 & 19 \\
Degree & Undergraduate & 103 & 56 \\
& Master & 41 & 22.3 \\
& Ph.D & 40 & 21.7 \\
Years of & $1^{\text {st }}$ Years & 68 & 37 \\
study & $2^{\text {nd }}$ Years & 37 & 20.1 \\
& $3^{\text {rd }}$ Years & 31 & 16.8 \\
& $4^{\text {th }}$ Years & 48 & 26.1 \\
\hline
\end{tabular}

\section{Instruments of Data Collection}

The data collection method used in this study was a questionnaire using a Likert scale. The questionnaire used consisted of four parts, namely, demographic information (gender, age, year of study, degree), academic stress, coping strategies, and academic achievement. The academic stress instrument is an adaptation of the instrument developed by Sinha, Sharma, \& Nepal (2001), named Scale for Assessment Academic Stress (SAAS). This scale consists of five subscales, namely cognitive, affective, physical, social/interpersonal, and motivational. The number of statements used was 30 items. Then the coping strategy instrument is an adaptation of Lin \& Chen (2010) under the name Stress Coping Style Inventory (SCSI). This inventory consists of four factors, namely active emotional coping, passive emotional coping, active problem coping, and passive problem coping. There are 28 statement items with a fourpoint type Likert scale as a choice of answers to the statements given on each instrument, ranging from strongly disagreeing, disagreeing, agreeing, and strongly agreeing. The variable and its aspect is shown in Table 2.
Table 2. Variable and Its Aspect

\begin{tabular}{lll}
\hline Variable & Aspect & Item \\
\hline Academic & Cognitive & $1,3,22,24,27,28,29$ \\
stress & Affective & $4,7,10,13,14,30$ \\
& Physical & $2,6,16,20,26$ \\
& Social/Interpersonal & $12,15,17,18,25$ \\
& Motivational & $5,8,9,11,19,21,23$ \\
Coping & Active emotional & $1,2,3,4,5,6,7,8$ \\
strategy & Passive emotional & $9,10,11,12,13,14$ \\
& Active problem & $15,16,17,18,19,20$ \\
& Passive problem & $21,22,23,24,25,26$, \\
& & 27,28 \\
\hline
\end{tabular}

To determine the feasibility of the instrument is to use a test of validity and reliability. Researchers conducted a pilot study by spreading the instrument to 50 students who were not research samples. The results of the pilot study carried out illustrate that all items in SAAS were declared valid $(r=.320$ to .836 , $p<.05)$ and reliable (Cronbach Alpha $=.951)$. While all items in SCSI are also declared valid $(r=.293$ to .655$)$ and reliable (Cronbach alpha $=.893)$. These results mean the instrument is suitable for use in research. Then for academic achievement is measured using a great point academic (GPA).

\section{Procedure and Data Analysis}

The scale that has been adjusted and declared valid and reliable is then distributed directly to students who are the research samples. Each student is given 40 minutes to fill in the scale according to the guidelines for filling in the scale, then submit the results to the researcher. After the data has been collected, the researcher checks it as a whole, then transforms the data and input it into excel format. After that the researchers analyzed the research data using SPSS version 23.0. To analyze the results of the research on the first research objective, the data analysis technique used was descriptive statistics (frequency and percentage), then for the analysis of the second research objective using descriptive statistic and multivariate analysis (using two prerequisite tests, namely normality and homogeneity), and for the analysis of the third research objectives using descriptive statistic and correlation. The level of significance for all data analyzes was $5 \%$. 


\section{FINDINGS AND DISCUSSION Findings}

Level of Academic Stress and Coping Strategy

The results of the descriptive analysis in Table 3 show that overall the academic stress variable for students is at a moderate level. Likewise, the coping strategy carried out by students is still at a moderate level as a whole.

Table 3. Frequency and Percentage: Level of Academic Stress and Coping Strategy among Respondent

\begin{tabular}{llccc}
\hline & & \multicolumn{3}{c}{ Percentage } \\
\cline { 3 - 5 } Variable & Aspect & $\begin{array}{c}\text { High/ } \\
\text { More }\end{array}$ & Middle & $\begin{array}{c}\text { Low/ } \\
\text { Less }\end{array}$ \\
\hline Academic & Cognitive & 23.4 & 62.5 & 14.1 \\
stress & Affective & 19.6 & 65.2 & 15.2 \\
& Physical & 10.3 & 72.8 & 16.9 \\
& Social & 12 & 66.8 & 21.2 \\
& Motivational & 17.4 & 65.8 & 16.8 \\
Coping & Active emotional & 73.9 & 23.9 & 2.2 \\
strategy & Passive emotional & 5.4 & 64.7 & 29.9 \\
& Active problem & $51.6 \%$ & 45.1 & 3.3 \\
& Passive problem & $12.5 \%$ & 80.4 & 7.1 \\
\hline
\end{tabular}

Differences in Academic Stress and Coping Strategies based on Gender, Age, Marital Status, Degree and Years of Study

The results of the kolmogorov smirnov test and levene test show that the data of academic stress and coping strategies are in normal position $(p=.420, .078>.05)$ and not homogeneous $(p=.000, .000<.05)$. Even though the data are not homogeneous, the Manova test is still carried out because the research samples are in large category (Huberty \& Morris, 1989).

The results of mean, $S D$, and multivariate analysis in Table 4 and Table 5 show that in gender variables, there are significant differences between male and female students related to academic stress and coping strategy with a value of $F(9)=3.242, p<.05$, and partial eta squared $=.039$. The age variable also shows a significant difference between students aged $<20$ years, 2030 years, $31-40$ years related to academic stress, and coping strategy with a value of $F(18)=$ $1.907, p<.05$, and partial eta squared $=.012$. The marital status variable shows that there are significant differences between students with single status and students with married status related to academic stress and coping strategy with a value of $F(9)=6.289, p<.05$, and partial eta squared $=.138$. The degree variable also shows a significant difference between a bachelor, master, and Ph.D. related to academic stress and coping strategy with a value of $F(18)$ $=3.051, p<.05$, and partial eta squared $=.060$. Then in the years of study variable, the results of the analysis also show that there are significant differences between $1^{\text {st }}$ year, $2^{\text {nd }}$ year, $3^{\text {rd }}$ year, and $4^{\text {th }}$ year students related to academic stress and coping strategy with a value of $F(27)=$ $3.777, p<.05$, and partial eta squared $=.069$.

Table 4. Mean and SD of Academic Stress and Coping Strategy based on Gender, Age, Marital Status, Degree, Years of Study

\begin{tabular}{|c|c|c|c|c|c|}
\hline \multirow{2}{*}{ Variable } & & \multicolumn{2}{|c|}{ Academic Stress } & \multicolumn{2}{|c|}{ Coping Strategy } \\
\hline & & $M$ & $S D$ & $M$ & $S D$ \\
\hline \multirow[t]{2}{*}{ Gender } & Male & 56.7 & 18.03 & 66.5 & 12.9 \\
\hline & Female & 63.7 & 17.7 & 66.8 & 12.6 \\
\hline \multirow[t]{3}{*}{ Age } & $<20$ & 63.2 & 17.8 & 64.5 & 11.2 \\
\hline & $20-30$ & 61.9 & 18.2 & 67.3 & 12.8 \\
\hline & $31-40$ & 50.2 & 15.2 & 64.3 & 14.2 \\
\hline \multirow[t]{2}{*}{ Marital status } & Single & 63.1 & 18.3 & 66.8 & 12.7 \\
\hline & Married & 51.5 & 13.6 & 66.3 & 12.9 \\
\hline \multirow{3}{*}{ Degree } & Undergraduate & 63.4 & 17.2 & 67.9 & 12.1 \\
\hline & Master & 64.4 & 16.9 & 65.2 & 11.9 \\
\hline & Ph.D & 51.1 & 18.3 & 64.9 & 14.9 \\
\hline \multirow{4}{*}{ Years of Study } & $1^{\text {st }}$ Years & 61.9 & 18.8 & 66.3 & 13.7 \\
\hline & $2^{\text {nd }}$ Years & 54.9 & 18.7 & 60.4 & 12.4 \\
\hline & $3^{\text {rd }}$ Years & 61.5 & 19.9 & 67.1 & 8.04 \\
\hline & $4^{\text {th }}$ Years & 63.7 & 14.5 & 71.8 & 11.9 \\
\hline
\end{tabular}


Table 5. Multivariate Analysis: Differences in Academic Stress and Coping Strategies based on Gender, Age, Marital Status, Degree, Years of Study

\begin{tabular}{lcccccc}
\hline Effect & Pillai's Trace & $\boldsymbol{F}$ Ratio & $\boldsymbol{d} \boldsymbol{f}$ & Error $\boldsymbol{d} \boldsymbol{f}$ & Sig of $\boldsymbol{F}$ & $\begin{array}{c}\text { Partial Eta } \\
\text { Squared }\end{array}$ \\
\hline Gender & .171 & 3.242 & 9 & 141 & .001 & .039 \\
Age & .216 & 1.907 & 18 & 284 & .015 & .012 \\
Marital status & .286 & 6.289 & 9 & 141 & .000 & .138 \\
Degree & .324 & 3.051 & 18 & 284 & .000 & .060 \\
Years of study & .576 & 3.777 & 27 & 429 & .000 & .069 \\
\hline
\end{tabular}

Relationship between Academic Stress and Coping Strategy with Academic Achievement

The correlation analysis results in Table 6 show that cognitive indicators have a significant positive relationship with active emotional coping $(p<.05)$, passive emotional coping ( $p$ $<.05)$ and passive problem coping $(p<.05)$. Affective indicators have a significant positive relationship with passive emotional coping ( $p$ $<.05)$ and passive problem coping $(p<.05)$. Physical indicators have a significant positive relationship with active emotional coping $(p<.05)$, passive emotional coping $(p<.05)$ and passive problem coping $(p<.05)$. Social indicators have a significant positive relationship with passive emotional coping $(p<.05)$ and passive problem coping $(p<.05)$. Motivational indicators have a significant positive relationship with passive emotional coping $(p<.05)$ and passive problem coping $(p<.05)$. The others do not show any significant correlations.

Table 6. Intercorrelations: Relationships between Academic Stress, Coping Strategy, and Academic Achievement

\begin{tabular}{lccccccccccc}
\hline Variable & $\boldsymbol{M}$ & $\boldsymbol{S D}$ & $\mathbf{1}$ & $\mathbf{2}$ & $\mathbf{3}$ & $\mathbf{4}$ & $\mathbf{5}$ & $\mathbf{6}$ & $\mathbf{7}$ & $\mathbf{8}$ & $\mathbf{9}$ \\
\hline Cognitive indicator & 14.9 & 4.8 & - & & & & & & & & \\
Affective indicator & 12.8 & 4.5 & $.820^{* *}$ & - & & & & & & \\
Physical indicator & 9.7 & 3.2 & $.653^{* *}$ & $.640^{* *}$ & - & & & & & \\
Social indicator & 9.5 & 3.6 & $.691^{* *}$ & $.694^{* *}$ & $.629^{* *}$ & - & & & & \\
Motivational indicator & 13.9 & 4.7 & $.727^{* *}$ & $.730^{* *}$ & $.569^{* *}$ & $.616^{* *}$ & - & & & \\
Active emotional coping & 23.8 & 5 & $.174^{*}$ & .117 & $.157^{*}$ & .071 & .075 & - & & \\
Passive emotional coping & 9.9 & 3.5 & $.402^{* *}$ & $.293^{* *}$ & $.428^{* *}$ & $.353^{* *}$ & $.300^{* *}$ & $.218^{* *}$ & - & & \\
Active problem coping & 16.4 & 3.9 & -.004 & -.051 & .137 & .018 & -.104 & $.646^{* *}$ & $.226^{* *}$ & - & \\
Passive problem coping & 16.5 & 4.3 & $.310^{* *}$ & $.170^{*}$ & $.340^{* *}$ & $.273^{* *}$ & $.223^{* *}$ & $.383^{* *}$ & $.546^{* *}$ & $.479^{* *}$ & - \\
GPA & 3.5 & .4 & .075 & .105 & .000 & .047 & -.075 & .085 & -.059 & -.022 & .013 \\
\hline
\end{tabular}

Note: $* p<.05, * * p<.01$

\section{Discussion}

The first objective is to analyze the level of academic stress and a coping strategy for students. The results of data analysis carried out show that the average value of each indicator in academic stress is at a moderate level. In accordance with Singh \& Kohli (2015) which shows that academic stress in students is at a moderate level. Students with stress levels in the medium category, individuals decide to focus more on things that are important at this time, then try to put aside things that are not important to narrow their perceptions (Stuart \& Sundeen, 2013). This means that students who have academic stress in the current category are more focused on the stressor and make stronger efforts to reduce stress in learning, thereby overriding other things that result in a narrow perception of other things that are ignored. The results also showed that academic stress on cognitive aspects was the most experienced indicator for students. This is indicated by difficulty concentrating in learning, easy to forget about the material that has been learned, difficult to solve problems in learning, difficult in answering various questions in learning, doubting the ability of self in learning, doubtful and afraid to ask questions about something that is not understood in learning.

These results are consistent with Holroyd 
\& Lazarus (1982) that explained cognitive is an indicator that plays a significant role in stress reactions. Whereas the coping strategy analysis shows that the most widely used sub-variables by students to suppress academic stress are active emotional coping, such as making yourself happier and more relaxed, telling the problem being faced to friends, calming themselves and reconciling negative emotions, eating and doing the beautiful thing, think of the problem as a challenge yourself, tell yourself always to survive / not give up. Lin \& Chen (2010) explain that someone who uses active emotional coping tries to overcome the problem at hand by adjusting themselves to the problem, thinking positive, encouraging themselves to solve problems, changing negative emotions, seeking help in adjusting/stabilizing emotions.

The second objective is to analyze the effect of different demographic factors on academic stress and coping strategies. The results showed differences in gender, age, marital status, degree, and years of study had a significant effect. Female are more dominant in each indicator compared to male. This shows that female experience more stress than male (Backović, Zivojinovic, Maksimovic, \& Maksimovic, 2012; Thawabieh \& Qaisy, 2012; Kumar \& Bhukar, 2013; Kumari \& Dhull, 2015; Rahmayani, Liza, \& Syah, 2017). The reason is possible because female judge an event as a more significant threat to themselves compared to male who tend to be relaxed in responding to various events (Miller \& Kirsch, 1987; Ptacek, Smith, Dodge, 1992). These results make it clear that male and female have different stress mechanisms (Compas, Slavin, Wagner, \& Vannatta, 1986; Swearingen \& Cohen, 1985).

Analysis of the average value on each indicator shows that stress decreases as age gets older. This means that as we get older, the students tend to be more able to control the academic stress that is felt so that coping is also done more effectively. Seiffge-Krenke (2000) explains that adolescents whose age is increasing will have a broader treasury of strategies and higher skills in describing problems from several different perspectives. This is because they are already familiar/familiar with various problems encountered (Boekaerts, 1996).

Single students have higher stress than students who are married. This can be because people who are not married have a higher level of loneliness than those who are married so that the stress they have is also higher (Taylor, Peplau, \& Sears, 1998). Although single students have close friends, but emotional ties are not like married couples (Walters, 2002). Masters students have higher stress levels on cognitive, affective, and social indicators; undergraduate students have higher stress levels on physical and motivational indicators, while Ph.D students do not dominate stress on each indicator. The researcher assumes that Ph.D students have good experience in learning so that they can reduce various stressors in learning.

First-year and fourth-year students have higher levels of stress. Numerous studies produce the same findings (Supe, 1998; Shaikh, Kahloon, Kazmi, Khalid, Nawaz, Khan, \& Khan, 2004; Sreeramareddy, Shankar, Binu, Mukhopadhyay, Ray, \& Menezes, 2007). Firstyear students have a high risk of stress due to being in a transition period (Towbes \& Cohen, 1996; Pancer, Hunsberger, Pratt, \& Alisat, 2000; Wintre \& Yaffe, 2000). Whereas in the fourth year, students experience stress on physical and motivational indicators. Long study duration can lead to boredom/fatigue, so that academic pressure is so hight to complete studies and find work after graduation tends to cause motivation to decrease, and physiological health becomes disrupted (Li \& Lin, 2003; Wang, 2005; Elias, Ping, \& Abdullah, 2011).

The results on the coping strategy variable show that between male and female have significant differences related to the level of use in reducing academic stress. Female are superior in active emotional coping strategies, passive emotional coping, and passive problem coping, whereas male are superior in active problem coping strategies. This is the same as some previous studies that confirm that in dealing with a problem female tend to change emotional responses more often, while male tend to focus more on the problem (Endler \& Parker, 1990; Ptacek et al., 1994; Matud, 2004). Students aged 20-30 years are superior in using various coping strategies to reduce academic stress. Hamarat, Thompson, Zabrucky, Steele, Matheny, \& Aysan (2001) revealed that the more mature a person is, the more effective coping used.

Single status students are superior in active emotional coping, passive emotional 
coping, and passive problem coping strategies, while married students are superior in active problem coping strategies. This is supported by Bodenmann (2005) who revealed that to deal with stress appropriately, a married person focuses more on the source of the problem and then influences each other against his partner. Undergraduate students are superior in the use of active and passive emotional coping, and passive problem coping, whereas students of $\mathrm{Ph} . \mathrm{D}$ are more superior in the use of active problem coping. Researchers assume that the higher the level of one's education, the more able to solve problems with full responsibility. Fourth year students are superior in all emotional coping and problem coping. The longer the duration of education undertaken by students, the more burdens of moral burdens, so that the impact on the use of increasingly complex coping.

The third objective is to analyze the relationship between academic stress, coping strategy and academic achievement. The analysis shows that passive emotional coping and passive problem coping have a significant positive relationship with all indicators of academic stress (cognitive, affective, physic, social, motivational). Students who use passive problem coping tend to prefer to avoid or run away from problems and the more severe consumption of alcohol to calm themselves, then those who use passive emotional coping tend to blame themselves, blame God, surrender, irritability and blame others (Lin \& Chen, 2010). The use of passive emotional coping and passive problem coping can be bad for students because it can cause mental stress and antisocial behavior (Pariat, Rynjah, Joplin, \& Kharjana, 2014) and can result in damage that cannot be cured (Pine \& Aroson, 1988).

Active emotional coping has a significant positive relationship with cognitive and physic indicators. Students who use this strategy tend to adjust themselves to problems, think positively, push themselves to solve problems, change negative emotions, seek help in adjusting / stabilizing emotions (Lin \& Chen, 2010). This strategy is effectively used and positively impacts individual growth (Pine \& Aroson, 1988). Whereas active problem coping does not have a significant relationship with all academic stress indicators. A significant positive relationship shows that when the indicators on academic stress increase, the coping strategy will also increase. In this study not all strategies have a positive relationship with all academic stress indicators, this is due to the adjustment between coping strategies used with stress indicators experienced by students (Crockett, Iturbide, Stone, McGinley, Raffaelli, \& Carlo, 2007), and the ability possessed in solving various problems (Slamet \& Markam, 2003).

Academic achievement does not have a significant relationship with every indicator on academic stress. This is same with the findings of Rafidah, Azizah, Mohd, \& Norzaidi (2009) who revealed that students with moderate academic stress have a satisfactory academic achievement index. Sanders \& Lushington (2002) explains that academic stress has a negative impact on academic achievement, but these two variables have a bad relationship. The results of this study confirm that no matter how much academic stress experienced by students because it does not have a significant impact on academic achievement if they can handle it well. This result contradicts some previous studies which revealed a significant negative relationship between academic stress and academic achievement (Herath, 2019). Furthermore, the results of the study also showed that each coping strategy did not have a significant relationship with academic achievement. Khan (2013) found that stress coping skills and academic achievement had not strong relationships. This means that the effectiveness of the use of coping is not accompanied by an increase in academic achievement. However, these results contradict some other studies which reveal that the use of coping can help students in improving academic performance so that it impacts on good academic achievement (Kadhiravan \& Kumar, 2012; Sullivan, 2010; Yazon et al., 2017).

The university can consider the findings of this research in making decisions regarding the implementation of learning. The students' academic stress is at a moderate level and is dominated by cognitive stress, so that they have the potential to experience learning failure. Although academic stress is not significantly related to academic achievement, it will be an obstacle for the students to get good academic achievement if it is not addressed immediately. The use of coping strategies is a good solution in dealing with academic stress. However, the 
results indicate that there are still some who have not been able to use coping strategies well so they need guidance from educators. The guidance can be carried out by teaching them about the proper and good use of coping strategies. Thus, they can control the academic stress they are experiencing.

\section{CONCLUSION}

The college students have a very high level of vulnerability to academic stress, because they get more numerous and varied stressors. Therefore, they are expected to have a good coping strategy so that they can control their academic stress which ultimately impact on good academic achievement. The findings show that the academic stress on the students is at a moderate level dominated by cognitive indicators. Meanwhile, coping strategies also have the same level, dominated by indicators of active emotional coping. The results of the study do not show a significant relationship between academic stress and coping strategies with academic achievement. It means that there are other factors with a greater dominance of academic achievement obtained by the students. The next researchers are expected to develop these research findings on the same respondents to examine other psychological factors that are predicted to have significant relationship with academic achievement.

\section{REFERENCES}

Agolla, J. E., \& Ongori, H. (2009). An assessment of academic stress among undergraduate students: The case of University of Bostwana. Educational research and review, 4(2), 063-067. https://academicjournals.org/journal/ ERR/article-full-text-pdf/5F4E7833647.

Alvin, N. (2007). Handling study stress: Panduan agar anda bisa belajar bersama anak-anak anda. [Handling study stress: A guide so you can study with your children]. Jakarta, Indonesia: Elex Media Komputindo. https://scholar.google.co.id/ scholar?cluster $=4498803600910993064$.

Backović, D. V., Zivojinovic, J. I., Maksimovic, J., \& Maksimovic, M. (2012). Gender differences in academic stress and burnout among medical students in final years of education. Psychiatria Danubina, 24(2), 175-181. http://www. psychiatria-danubina.com/2012-vol-24no-2/481?tip $=\&$ datum od $=\&$ datum $\underline{\mathrm{do}}=\&$ detalji $=481 \& \mathrm{z}=$ \&page $=3$.

Bamuhair, S. S., Al Farhan, A. I., Althubaiti, A., Agha, S., Rahman, S. U., \& Ibrahim, N. O. (2015). Sources of stress and coping strategies among undergraduate medical students enrolled in a problembased learning curriculum. Journal of Biomedical Education, 2015(10), 1-8. https://doi.org/10.1155/2015/575139.

Bernstein, E. R. D., Penner, L. A., \& ClarkeStewart, A. (2008). Psychology $\left(8^{\text {th }}\right.$ ed). New York, NY: Houghton Mifflin Company.

Boekaerts, M. (1996). Coping with stress in childhood and adolescence. In M. Zeidner \& S. Endler (Eds.). Handbook of coping: Theory, research, applications. New York, NY: John. Wiley \& Sons, pp. 452-484. https://psycnet.apa.org/ record/1996-97004-020.

Compas, B. E., Slavin, L. A., Wagner, B. M., \& Vannatta, K. (1986). Relationship of life events and social support with psychological dysfunction among adolescents. Journal of Youth and Adolescence volume, 15(3), 205-221. https://doi.org/10.1007/BF02139123.

Cooper, C. L., \& Payne, R. L. (1991). Personality and stress: individual differences in the stress process. New York, NY: John Wiley and Sons.

Creswell, J. W. (2014). Research design: Qualitative, quantitative, and mixed methods approaches $\left(4^{\text {th }}\right.$ ed). Thousand Oaks, CA: Sage.

Crockett, L. J., Iturbide, M. I., Stone, R. A. T., McGinley, M., Raffaelli, M., \& Carlo, G. (2007). Acculturativestress, social support, and coping: Relations to psychological adjustment among Mexican American college students. Cultural Diversity and Ethnic MinorityPsychology, 13(4), 347-355. https://doi.org/10.1037/1099- 
9809.13.4.347.

Elias, H., Ping, W. S., \& Abdullah, M. C. (2011). Stress and academic achievement among undergraduate students in Universiti Putra Malaysia. ProcediaSocial and Behavioural Sciences, 29(1), 646-655. https://doi.org/10.1016/j. sbspro.2011.11.288.

Endler, N. S., \& Parker, J. D. (1990). Multidimensional assessment of coping: A critical evaluation. Journal of Personality and Social Psychology, 58(5), 844-854. https://doi.org/10.1037/00223514.58.5.844.

Folkman, S., \& Lazarus, R. S. (1985). If it changes it must be a process: Study of emotion and coping during three stages of a college examination. Journal of Personality and Social Psychology, 48(1), 150-170. https://doi.org/10.1037/00223514.48.1.150.

Govaerst, S., \& Gregoire, J. (2004). Stressful academic situations: Study on appraisal variables in adolescence. European Review of Applied Psychology, 54(4), 261-271. $\quad$ https://doi.org/10.1016/j. erap.2004.05.001.

Haber, A., \& Runyon, R. P. (1984). Psychology of adjustment. Homewood, Illinois: The Dorsey Press.

Hamarat, E., Thompson, D., Zabrucky, K. M., Steele, D., Matheny, K. B., \& Aysan, F. (2001). Perceived stress and coping resource availability as predictors of life satisfaction in young, middle-aged, and older adults. Experimental Aging Research, 27(2), 181-196. https://doi. org/10.1080/036107301750074051.

Herath, H. M. W. M. (2019). Relationship between academic stress and academic achievements of the undergraduate students in Sri Lanka - A case study of undergraduates in Uva Wellassa University. Global Journal of HumanSocial Science Research, 19(7A), 1-7. https://socialscienceresearch.org/index. php/GJHSS/article/view/2884.
Hicks, T. \& Hestie, S. (2008). High school to college transition: A profile of the stressor, physical, and psychological health issues that effect the first year on-campus collage student. Journal of Cultural Diversity, 15(3), 143-147. http://digitalcommons. uncfsu.edu/soe faculty wp/14.

Holroyd, K. A., \& Lazarus, R. S. (1982). Stress, coping and somatic adaptation. In L. Goldberger \& S. Breznitz (Eds.). Handbook of stress: Theoretical and clinical aspects. New York, NY: Free Press, pp. 21-35.

Huberty, C. J., \& Morris, J. D. (1989). Multivariate analysis versus multiple univariate analyses. Psychological Bulletin, 105(2), 302-308. https://doi. org/10.1037/0033-2909.105.2.302.

Hung, C. - L. (2011). Coping strategies of primary school teachers in Taiwan experiencing stress because of teacher surplus. Social Behavior and Personality, 39(9), 1161-1173. https://doi.org/10.2224/ sbp.2011.39.9.1161.

Kadhiravan, S., \& Kumar, K. (2012). Enhancing stress coping skills among college students. Researchers World: International Refereed Social Sciences Journal, 3(4/1), 49-55. http://www. researchersworld.com/index.php/rworld/ article/view/680.

Kariv, D., \& Heiman, T. (2005). Task-oriented versus emotion-oriented coping strategies: The case of college students. College Student Journal, 39(1), 72-89. https:// www.ingentaconnect.com/content/prin/ csj/.

Khan, M. (2013). Academic self efficacy, coping, and academic performance in college. International Journal of Undergraduate Research and Creative Activities, 5(1), 1-11. http://doi. org/10.7710/2168-0620.1006.

Kumar, S., \& Bhukar, J. P. (2013). Stress level and coping strategies of college students. Journal of Physical Education and Sport Management, 4(1), 5-11. https://doi. 
org/10.5897/JPESM12.001.

Kumari, S. \& Dhull, I. (2015). Academic stress among adolescents in relation to gender. International Journal of Applied Research, 1(11), 394-396. https://www. allresearchjournal.com/archives/?year $=2$ $015 \&$ vol $=1 \&$ issue $=11 \&$ part $=$ F\&Article $\underline{\mathrm{Id}=931}$.

Lal, K. (2014). Academic stress among adolescent in relation to intelligence and demographic factors. American International Journal of Research in Humanities, Arts and Social Sciences, 5(1), 123-129. http://iasir.net/ AIJRHASSpapers/AIJRHASS14-150. pdf.

Lazarus, R. S. (1976). Pattern of adjustment. New York, NY: Mc Graw Hill.

Lazarus, R. S., \& Folkman, S. (1984). Stress, appraisal, and coping. New York, NY: Springer.

Lerner, B. A. (1995). Students' use of psychiatric services: The Columbia experience. The Journal of the American Medical Association, 274(17), 1398-1399. https:// doi.org/10.1001/jama.274.17.1398.

Li, H., \& Lin, C. (2003). College stress and psychological well-being of Chinese college students. Acta Psychological Sinica, 35(2), 222-230. http://journal. psych.ac.cn/x1xb/EN/Y2003/V35/ $\underline{\mathrm{I} 02 / 222}$.

Lin, Y. M., \& Chen, F. S. (2010). A stress coping style inventory of students at universities and colleges of technology. World Transactions on Engineering and Technology Education, 8(1), 67-72. http:// www.wiete.com.au/journals/WTE\&TE/ Pages/TOC V8N1.html.

Matud, M. P. (2004) Gender differences in stress and coping styles. Personality and Individual Differences, 37(7), 1401-1415. $\quad$ https://doi.org/10.1016/j. paid.2004.01.010.

Miller, S. M., \& Kirsch, N. (1987). Sex differences in cognitive coping with stress. In R. C. Barnett, L. Biener, \& G. K. Baruch (Eds.). Gender \& Stress. New York, NY: Free Press, pp. 278-307.

Mulinda, S., \& Megawati, M. (2018). Pengaruh harga diri dan stress terhadap prestasi akademik dikalangan mahasiswa di fakultas ekonomi dan bisnis, Universitas Syiah Kuala. [Effect of self-esteem and stress on academic achievement among students at the Faculty of Economics and Business, Syiah Kuala University]. Jurnal Ilmiah Mahasiswa Ekonomi Manajemen, 3(3), 49-58. http://jim.unsyiah.ac.id/ EKM/article/view/8084.

Oktarisa, F., \& Yusra, Z. (2015). Perbedaan prestasi akademik ditinjau dari coping strsess dan jenis kelamin pada pers mahasiswa. [Differences in academic achievement in terms of coping with stress and gender in the student press]. Jurnal RAP UNP, 6(2), 136-145. http:// ejournal.unp.ac.id/index.php/psikologi/ article/view/6617.

Olejnik, S. N., \& Holschuh, J. P. (2007). College rules: How to study, survive, and succeed ( $2^{\text {nd }} e d$ ). New York, NY: Ten Speed Press.

Pancer, S. M., Hunsberger, B., Pratt, M. W., \& Alisat, S. (2000). Cognitive complexity of expectations and adjustment to university in the first year. Journal of Adolescent Research, 15(1), 38-57. https://doi. org/10.1177\%2F0743558400151003.

Pariat, L., Rynjah, A., Joplin, J. \& Kharjana, M. G. (2014). Stress level of college students: Interrelationship between stressors and coping strategies. Journal of Humanities and Social Sciences, 19(8), 40-46. https:// doi.org/10.9790/0837-19834046.

Pine, A., \& Aroson, E. (1988). Career burnout: Causes and cures. New York, NY: Free Press.

Price, J. H. (1985). A model for explaining adolescent stress. Health Education, 16(3), 36-40. https://doi.org/10.1080/009 70050.1985.10614469. 
Ptacek, J. T., Smith, R. E., Dodge, K. L. (1994). Gender differences in coping with stress: When stressors and appraisal do not differ. Personality and Social Psychology Bulletin, 20(4), 421-430. https://doi. org/10.1177/0146167294204009.

Rafidah, K., Azizah, M. A., Mohd, M., \& Norzaidi, M. D. (2009). Stress and academic performance: Empirical evidence from university students. Academy of Educational Leadership Journal, 13(1), 37-51. https://www. researchgate.net/publication/299615555.

Rahmah, D. N. (2013). Hubungan self efficacy, coping stress dan prestasi akademik. [Relationship of self efficacy, stress coping and academic achievement]. Jurnal Ecopsy, 1(1), 7-14. https://doi. org/10.20527/ecopsy.v1i1.477.

Rahmayani, R. D., Liza, R. G., \& Syah, N. A. (2019). Gambaran tingkat stres berdasarkan stressor pada mahasiswa kedokteran tahun pertama program studi profesi dokter fakultas kedokteran universitas andalas angkatan 2017. [An overview of stress levels based on stressors in first year medical students of the medical profession study program at the Faculty of Medicine, Andalas University, class of 2017]. Jurnal Kesehatan Andalas, 8(1), 103-111. https://doi.org/10.25077/ jka.v8i1.977.

Sanders, A. E., \& Lushington, K. (2002). Effect of perceived stress on students' performance in dental school. Journal of Dental Education, 66(1), 75-81. https://doi.org/10.1002/j.00220337.2002.66.1.tb03510.x.

Santrock, J. W. (2003). Adolescence. (S. B. Adelar \& S. Saragih, Trans.). Jakarta, Indonesia: Erlangga.

Sarafino, E. P. (2002). Health psychology: Biopsychosocial interactions $\left(4^{\text {th }}\right.$ ed). New Jersey, NJ: HN Wiley.

Sarafino, E. P., \& Smith, T. W. (2012). Health psychology: Biopsychosocial interactions ( $7^{\text {th }}$ ed). New Jersey, NJ: John Wiley \&
Sons Inc.

Seiffge-Krenke, I. (2000). Causal links between stressful events, coping styles, and adolescent symptomatology. Journal of Adolescence, 23(6), 675-691. https://doi. org/10.1006/jado.2000.0352.

Shaikh, B. T., Kahloon, A., Kazmi, M., Khalid, H., Nawaz, K., Khan, N., \& Khan, S. (2004). Students, stress and coping strategies: a case of Pakistani medical school. Education for Health, 17(3), 346-353. https://pubmed.ncbi.nlm.nih. gov/15848822/.

Singh, N., \& Kohli, C. (2015). Stress reaction and coping strategies among nursing students in Delhi. Asian Journal of Nursing Education and Research, 5(2), 274-278. https://doi.org/10.5958/23492996.2015.00054.3.

Sinha, U. K., Sharma, V., \& Nepal, M. K. (2001). Development of a scale for assessing academic stress: A preliminary report. Journal of the Institute of Medicine, 23(1\&2), 105-102. https://www. semanticscholar.org/paper/46759cc82480 f71a5172b15d8c350b1046549f71.

Slamet, S. I. S, \& Markam, S. (2003). Pengantar psikologi klinis. [Introduction to clinical psychology]. Jakarta, Indonesia: UI Press.

Sreeramareddy, C. T., Shankar, P. R., Binu, V. S., Mukhopadhyay, C., Ray, B., \& Menezes, R. G. (2007). Psychological morbidity, sources of stress and coping strategies among undergraduate medical students of Nepal. BMC Medical Education, 7(26), 1-8. https://doi.org/10.1186/1472-69207-26.

Stallard, E. (2004). Health psychology. New York, NY: MC. Graw Hill.

Stuart, G. W., \& Sundenen, S. J. (2013). Principles practice psychiatric nursing (A. Y. S. Hamid, Trans.). Jakarta, Indonesia: EGC. (Original work published 2001).

Sullivan, J. R. (2010). Preliminary psychometric data for the academic coping strategies 
scale. Assessment for Effective Intervention, 35(2), 114-127. https://doi. org/10.1177\%2F 1534508408327609 .

Supe, A. N. (1998). A study of stress in medical students at Seth G. S. Medical College. Journal of Postgraduate Medicine, 44(1), 1-6. https://www.jpgmonline.com/text. asp?1998/44/1/1/389.

Swearingen, E. M., \& Cohen, L. H. (1985). Life events and psychological distress: a prospective study of young adolescents. Developmental Psychology, 21(6), 1045-1054. https://doi.org/10.1037/0012$\underline{1649.21 .6 .1045}$

Taylor, S. E., Peplau, L. A., \& Sears, D. O. (2006). Social Psychology (12 ${ }^{\text {th }}$ ed). New Jersey, NJ: Pearson Prentice Hall.

Thawabieh, A. M. \& Qaisy, L. M. (2012). Assessing stress among university students. American International Journal of Contemporary Research, 2(2), 110 116. http://www.aijcrnet.com/journals/ Vol 2_No_2 February_2012/13.pdf.

Towbes, L. C., \& Cohen, L. H. (1996). Chronic stress in the lives of college students: Scale development and prospective prediction of distress. Journal of Youth and Adolescence, 25(2), 199-217. https:// doi.org/10.1007/BF01537344.
Walters, J. D. (2002). Expansive marriage: $A$ way to self realization (Wakidi, Trans.). Yogyakarta, Indonesia: Kanisius. (Original work published 1995).

Wang, C. (2005). Investigation on the stress state of undergraduate. Chinese Journal of Health Psychology, 13(4), 311-313. https://caod.oriprobe.com/ articles/9093151/Invertigation on the Stress_State of Undergraduate.htm.

Wintre, M. G., \& Yaffe, M. (2000). Firstyear students' adjustment to university life as a function of relationships with parents. Journal of Adolescent Research, 15(1), 9-37. https://doi. org $/ 10.1177 \% 2 \mathrm{~F} 0743558400151002$.

Yazon, A. D., Ang-Manaig, K., \& Tesoro, J. F. B. (2018). Coping mechanism and academic performance among Filipino undergraduate students. $K n E$ Social Science, 3(6), 30-42. https://doi. org/10.18502/kss.v3i6.2372.

Yusoff, M. (2010). Stress, stressors and coping strategies among secondary school students in a Malaysian government secondary school: Initial findings. ASEAN Journal of Psychiatry, 11(2), 1-15. http:// citeseerx.ist.psu.edu/viewdoc/download? $\underline{\text { doi }}=10.1 .1 .385 .2939 \& \mathrm{rep}=$ rep1\&type $=p$ df. 